Table 1

The Effect of Changing Air Flow on Absolute Odor Detection Thresholds for Methyl Isobutyl Ketone

\begin{tabular}{ccc}
\hline Subject & $\begin{array}{c}\text { Air Flow } \\
(1 \mathrm{~min})\end{array}$ & $\begin{array}{c}\text { Threshold Conc. } \\
\mathrm{mg} / 1\end{array}$ \\
\hline 1 & 247.0 & .0010 \\
& 326.0 & .0010 \\
2 & 247.0 & .0009 \\
& 293.3 & .0009 \\
& 326.0 & .0008 \\
\hline
\end{tabular}

The thresholds were determined using a modified tracking procedure (Stone et al, 1967); $S$ received 50 trials in a session in which half of the presentations were blanks and half were stimuli. Similar results were obtained with several other Ss.

desorbs) any of the test stimuli was given careful consideration. Attempts to demonstrate this (by chemical means) were not successful, primarily because of the nonstatic nature of the system; i.e., the air was always flowing at a rate greater than $200 \mathrm{l} / \mathrm{min}$ (a complete changeover of the space occurred in less than $2 \mathrm{sec}$ ). As a precautionary measure, after each test session the walls are rinsed with acetone and warm distilled water, then wiped dry.

\section{REFERENCES}

AMERINE, M. A., PANGBORN, R. M., \& ROESSLER, E. B. Principles of sensory evaluation of food. Ncw York: Academic Press, 1965.

ELSBERG, C. A., \& LEVY, I. The sense of smell: I. A new and simple method of quantitative olfactometry. Bulletin of the Neurological Institute of New York, 1935, 4, 5-19.

JONES, I. N. A test of the Elsberg technique of olfactometry. American Journal of Psychology, 1953, 66, 81-85.
OUGH, C. S., \& STONE, H. An olfactometer for rapid and critical odor measurement. Joumal of Food Sciences, 1961, 26, 452-456.

STONE, H. Physiological and psychological aspects of the olfactory response of man. In $\mathrm{N}$. Tanyolac (Ed.), Theories of odors and odor measurement. England: Technivision, 1968.

STONE, H. Some factors affecting olfactory sensitivity and odor intensity. Thesis. University of California at Davis, $112 \mathrm{pp} ., 1963 \mathrm{~b}$.

STONE, $H$. Techniques for odor measurement: Olfactometric vs. sniffing. Joumal of Food Sciences, 1963a, 2, 719-725.

STONE, H., \& BOSLEY, J. J. Olfactory discrimination and Weber's Law. Perceptual \& Motor Skills, 1965, 20, 657-665.

STONE, H., PANGBORN, R. M., \& OUGH, C. S. Techniques for sensory evaluation of food odors. Advanced Food Research, 1965, 14, 1-32.

STONE, H., PRYOR, G., \& COLWELL, J. Olfactory detection thresholds in man under conditions of rest and exercise. Perception \& Psychophysics, 1967, 2, 167-170.

STUIVER, M. Biophysics of the sense of smell. Thesis. Groningen University, The Netherlands, 99 pp., 1958.

WENZEL, B. M. Olfactometric method utilizing natural breathing in odor-free "environment." Science, 1955, 121, 802-803.

ZWAARDEMAKER, H. A camera inodorata. Perfumery Essential Oil Record, 1921, 12, 243-244.

\section{NOTES}

1. This research was supported in part by Grant No. NB 07832 from the Institute of Neurological Sciences of the National Institutes of Health to $\mathrm{H}$. Stone and in part by Grant No. 2002 FR-05522 from the Division of Facilities Resources. The authors acknowledge the advice and assistance of Mr. John S. Loram in design of the circuitry and of numerous staff members who participated as subjects.

2. Address: Life Sciences Division, Stanford Research Institute, Menlo Park, California 94025.

3. Stone, H., Pryor, G., \& Steinmetz, G. A comparison of two psychophysical techniques for the study of olfactory adaptation and recovery in man. Unpublished manuscript, 1969.

4. Stone, H., \& Pryor, G. Unpublished laboratory report, 1967.

\title{
A simple tachistoscope for student labs
}

\author{
RICHARD O. ROUSE and ROGER M. TARPY, WILLIAMS \\ COLLEGE, Williamstown, Mass. 01267
}

An inexpensive tachistoscope for student labs is described that utilizes a camera shutter to control exposure duration and a potentiometer to vary light intensity. Stimuli can be drawn or typed on $3 \times 5$ index cards.

There have been few notes on the construction of simple and inexpensive tachistoscopes. Most accounts concern special adaptations or designs that are too complicated for student lab use (Behr, 1960; Howard \& Evans, 1964). The present paper describes a simple tachistoscope that can be built inexpensively for use in student labs.

The basic component in this design is a camera shutter (llex Optical Company, Rochester, New York, No. 1 Universal, $\$ 28.00$ ) that is mounted on one wall of a wooden box directly opposite a $2 \times 4$-in. opening. The inside dimensions of the box are 6 in. high $\times 8$ in. wide $\times 10 \frac{1}{2}$ in. long. On the outside of the opening is a card holder made from grooved, wooden strips that center a standard $3 \times 5$-in. index card in the window (see Fig. 1). On the inside wall (placed $1 / 2$ in. from the shutter on three sides) are located three 3-V flashlight bulbs wired in parallel. The wires extend under the lid of the box to two flashlight battery brackets. With the inside of the box painted white, illumination from the bulbs is bright enough to offset any leakage from the card opening. Furthermore, it is possible to wire a small potentiometer (e.g., Clarostat, A 43-20, 93q) in series with the

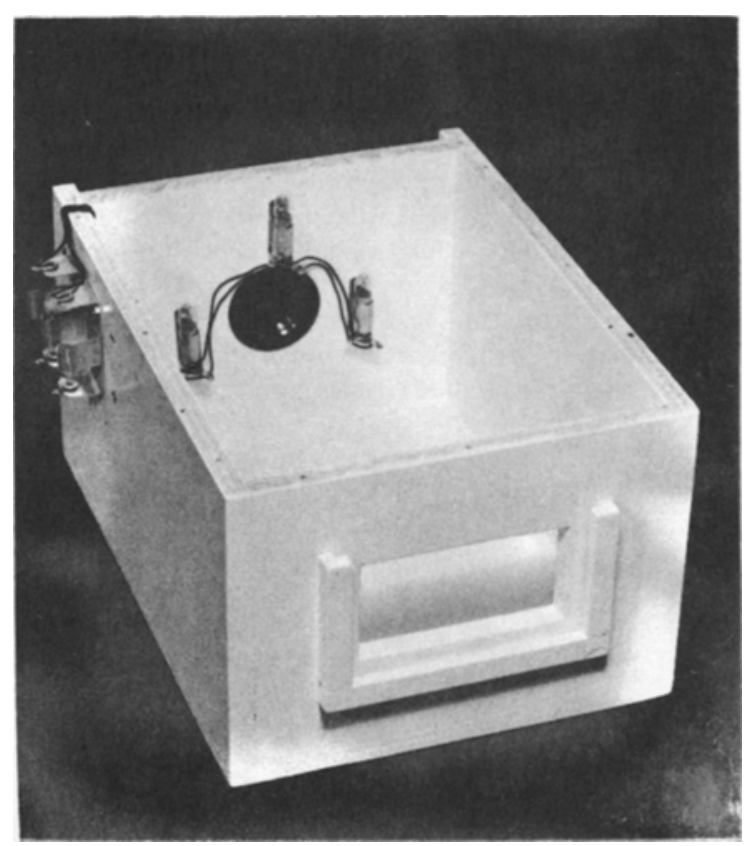

Fig. 1. Back view of the tachistoscope for student lab use (cover omitted). 
lights so that the illumination level can be varied. Under those conditions, a cardboard backing for each stimulus would be needed to prevent external light, which penetrates the card, from changing the inside illumination.

Since $3 \times 5$ index cards are used, it is a simple matter to make stimuli; the distance from the shutter to the card is 11 in. making typewriter letters readily visible. The particular shutter suggested can vary duration of exposure from $1 \mathrm{sec}$ through $1 / 100 \mathrm{sec}$; the opening of the diaphragm can be varied as well. The two primary disadvantages of this apparatus are that no focal point is provided other than the center of the diaphragm itself, and that the S's eye tends to dark-adapt if brought too close to the shutter.

The shutters mentioned above have been used for a number of years without any appreciable wear. The apparatus is superior to those using a "guillotine" door (Bugelski, 1951), the sectored rotating disk (Ferree \& Rand, 1937), and the dual mirror arrangement (Lvans, 1931) because of its simple, compact desigr and because both duration of exposure and intensity $o$ illumination can be varied systematically. Users must, however take note that leaf shutters such as this are not reliable enougl for research, since exposures at a given setting vary by as much a $10 \%$.

\section{REFERENCES}

BEHR, I. A new tachistoscope for animals and man. American Journal 0 Psychology, 1960, 73, 305-306.

BUGELSKI, B. R. Experimental psychology. New York: Holt \& Company 1951. Pp. 83-84.

EVANS, J. E. A tachistoscope for exposing large areas. American Journa of Psychology, 1931, 43, 285-286.

FERREE, C. E., \& RAND, G. A multipleexposure tachistoscope. Journa of Experimental Psychology, 1937, 21, 240-259.

HOWARD, I. P., \& EVANS, J. A. A new splitbeam tachistoscope giving a exact color-match. American Journal of Psychology, 1964, 77, 311-312

\section{A device for rapid recording of positioning responses in two dimensions'}

JOSEPH A. BAUER, JR., GORDON D. WOODS, and RICHARD HELD, DEPARTMENT OF PSYCHOLOGY, MASSACHUSETTS INSTITUTE OF TECHNOLOGY, Cambridge, Massachusetts 02139

A device for rapid recording of positioning responses is described. It utilizes an extremely simple, low-cost position transducer and two digital voltmeters or their equivalent. The device has the advantages of rapid, accurate measurement, reliability, ease of reading, and the potential for automatic recording of positional data in two dimensions.

In the study of sensorimotor coordination, pointing at a target is often used as a response and the appropriate response measure is the position of the tip of the index finger relative to the target position or to some arbitrary origin (Efstathiou, Bauer, Greene, \& Held, 1967; Holding, 1968; Keele \& Posner, 1968). If the $S$ holds a pencil in his hand while pointing, the position at which he touches it to a surface can be recorded on a piece of paper. However, the use of pencil marks on paper has three major disadvantages: First, as the number of data points increases, the problem of distinguishing overlapping markings arises. Secondly, the sequential order of markings is lost unless each response is numbered as it is made. Thirdly, as the amount of data collected increases, the time required for numerical transcription increases rapidly even if positions of marks are measured in only one direction (i.e., horizontal). It takes far longer for the $\mathrm{E}$ to transcribe a response than for the $S$ to make it. For these reasons, we have designed and constructed a system for rapid numerical recording in two dimensions of the end position of a response.

The system consists of three interconnected functional units. The first is the position transducer, which provides an electrical signal proportional to position. The second is a voltmeter, which measures and displays the signal from the transducer. The third is a control unit, which governs the sequential operation of the other two. Except for the position transducer, the actual choice of components is determined by the degree of automation desired for data acquisition and the estimated total cost of the system.

A scheme for implementing Teledeltos ${ }^{2}$ paper in a two-dimensional position transducer has been developed by
Blount (1967). Teledeltos paper is a metalized sheet of unifom electrical resistance in all directions across its surface. It can b bonded to plywood or hardboard with photographic $\mathrm{dr}$. mounting tissue. Figure 1 shows electrical connection of Teledeltos paper-covered board. The appropriate leads of th diodes are inserted through holes in the board spaced at 1 -in intervals. A spot of conducting paint at each junction make electrical connection between the diode and paper. When the bia voltage (V) is positive, as defined in Fig. 1, current will flow onl in the horizontal direction through the diodes along the vertic: sides. The current flow is uniform across vertical sections of th surface because of the spacing of the diodes, and the diodes alon

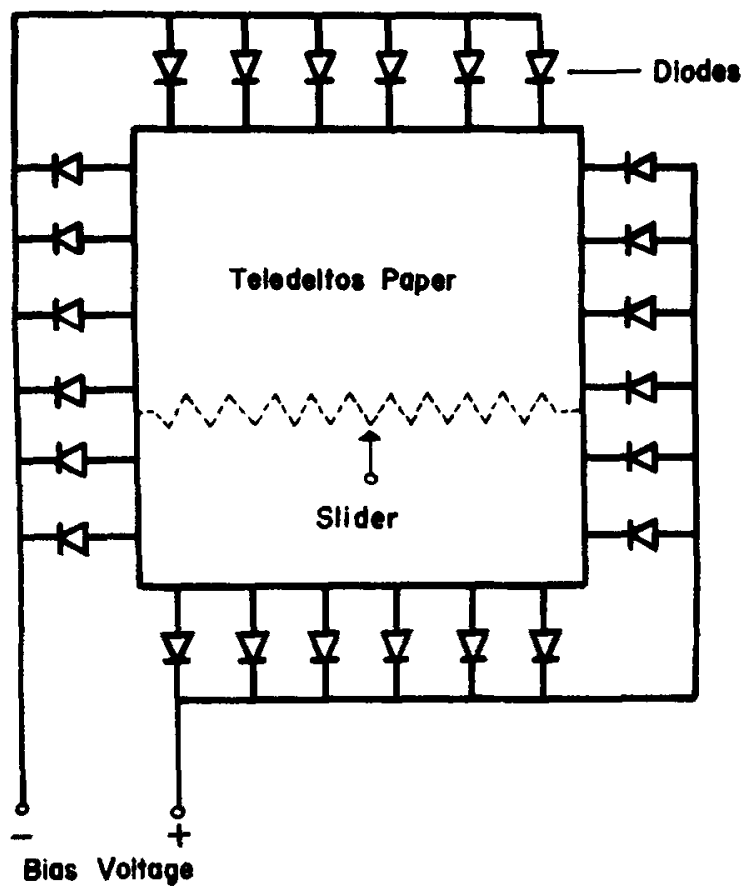

Fig. 1. Teledeltos board connections. 